\title{
OPINIÃO
}

\section{Uma nova política cambial para o país ${ }^{36}$}

\author{
José Luis Oreiro* \\ Luciano Rodrigues Lara**
}

Após a implantação do Real, em julho de 1994, o Brasil passou por um momento de indecisão quanto ao regime cambial a ser adotado e em 1995 optou-se pela adoção de bandas cambiais. Após diversos ataques especulativos, que tinham como causas as sucessivas crises cambiais ocorridas no resto do mundo (México em 1994, Sudeste Asiático em 1997 e Rússia em 1998), é adotado o regime de câmbio flutuante, em janeiro de 1999. Desde então o câmbio flutuante no Brasil ficou caracterizado pela volatilidade, alternando períodos de grande apreciação (atual) e grande depreciação (2002). Essa volatilidade é um problema grave porque os agentes são levados a postergar suas decisões, notadamente aqueles investimentos voltados para exportação, em razão de não conseguirem calcular seu retorno. Além disso, a apreciação cambial acarreta perda de competitividade para as exportações, em especial nos setores têxtil, de calçados e automóveis, havendo inclusive indícios crescentes de desindustrialização em função da forte apreciação da taxa de câmbio.

Nesse contexto, iremos apresentar uma proposta de regime cambial que auxiliará na redução desses problemas, reduzindo a volatilidade da taxa de câmbio e garantindo a competitividade para as exportações no longo prazo.

A proposta baseia-se no regime de banda de monitoramento que foi proposto pelo Comitê de Tarapore para o Banco Central da Índia. A idéia geral é de que o novo regime seria um sistema de bandas em que o BC teria flexibilidade de intervenção, isto é, não haveria obrigação de intervenção caso a taxa de câmbio saísse da banda.

Neste novo regime, o Banco Central utilizaria os seus instrumentos de forma a alcançar a taxa de câmbio real efetiva neutra (TCREN), calculada com base na média ponderada do índice de paridade do poder de compra dos maiores parceiros comerciais do país. A TCREN a ser perseguida seria definida pelo Conselho Monetário Nacional (CMN), tendo por objetivo manter a competitividade das exportações brasileiras no longo prazo. A partir da TCREN, o CMN definiria a taxa de câmbio nominal que seria o centro da banda.

\footnotetext{
36 Texto publicado no jornal Valor econômico, $1^{\circ}$ caderno, 13/12/2006.

* Doutor em Economia (IE/UFRJ), Professor Adjunto do Departamento de Economia da UFPR, Diretor do CEPEC/UFPR e Pesquisador do CNPq. E-mail: joreiro@,ufpr.br. Página pessoal: www.joseluisoreiro.ecn.br.

** Graduação em Ciências Econômicas pela Universidade Federal do Paraná. Bolsista do Programa de Educação Tutorial (PET). E-mail: lucianorlara@gmail.com.
} 
A largura da banda seria de mais ou menos $2,5 \%$ em torno do centro. As intervenções, para que a taxa de câmbio nominal fosse alterada, seriam feitas no mercado à vista de câmbio, ocorrendo em grandes volumes e de forma esporádica. Seguindo o conceito do regime de banda de monitoramento, as intervenções ocorreriam apenas fora da banda e apenas nos casos em que a autoridade monetária considere necessária. Este ponto é de extrema importância: não haveria por parte do Banco Central do Brasil a obrigação de intervir no mercado de câmbio. A autoridade monetária também teria liberdade para decidir a respeito da realização ou não de operações de esterilização, com vistas à "enxugar" os efeitos das operações de compra de reservas sobre a base monetária.

Para garantir a transparência do novo regime, antes da implantação do mesmo, seria publicado um relatório informando os principais pontos do regime cambial, entre eles: que o regime tem por objetivo a estabilidade da taxa de câmbio; que o centro da banda será estabelecido pelo Conselho Monetário Nacional, mas o valor do mesmo será informação confidencial das autoridades monetárias; que para buscar o objetivo acima mencionado serão feitas intervenções no mercado à vista de câmbio e que, por fim, a autoridade monetária decidirá sobre a conveniência ou não de operações de esterilização. Além disso, será divulgado mensalmente um relatório que apresentará todas as informações sobre as intervenções e esterilizações.

Dado que o Brasil utiliza atualmente um regime de metas de inflação como arcabouço para a condução da sua política monetária, a primeira questão que surge ao se propor um regime de câmbio administrado é se o regime de metas de inflação seria compatível com uma política ativa de administração da taxa de câmbio. A resposta a essa questão é positiva. Segundo o argumento da trindade impossível, com base no assim chamado modelo Mundell-Fleming, não é possível que uma economia aberta tenha política monetária independente, estabilidade da taxa de câmbio nominal e mobilidade de capitais. Um destes três objetivos deve ser sacrificado.

Sendo assim, para se garantir a compatibilidade entre uma política monetária independente (metas de inflação) e estabilidade da taxa nominal de câmbio (banda de monitoramento) é necessário uma redução significativa do grau de abertura financeira da economia brasileira por intermédio a adoção de controles a entrada de capitais, tal como é feito nos países que administram a sua taxa de câmbio como, por exemplo, a China e a Índia.

Uma proposta concreta nesse sentido seria a adoção de um depósito compulsório não-remunerado de cerca de 30\% sobre o valor de todos os investimentos externos feitos na 176 
economia brasileira por um prazo inferior a um ano. Um outro mecanismo seria a adoção de uma alíquota de IOF decrescente com o prazo médio de aplicação dos recursos externos na economia brasileira, de forma a alongar o prazo médio dos investimentos financeiros externos no Brasil. Nesse contexto, poderia ser adotado um IOF de 30\% para aplicações inferiores a um ano, 25\% para aplicações entre 1 e 2 anos, 20\% para aplicações entre 2 e 3 anos, 15\% para aplicações entre 3 e 4 anos, 10\% para aplicações entre 4 e 5 anos e isenção de IOF para aplicações superiores a 5 anos. Essas alíquotas seriam aplicadas apenas sobre a entrada de novos recursos, ficando isentos de tributação especial os recursos que tiverem entrado no país em data anterior a adoção do novo regime cambial.

Deve-se ressaltar também que entre os BRICs (Brasil, Rússia, Índia e China), o Brasil é o único que não tem um regime de câmbio administrado; sendo talvez essa uma das razões pelas quais o nosso país apresenta uma performance de crescimento muito inferior a observada nesses países. 
